\title{
Occurrence and health hazard status of aflatoxin in human food and animal feed of wheat from Pakistan: A review paper
}

\author{
Abdul Kabir Khan Achakzai ${ }^{1 *}$, Samiullah ${ }^{2}$, Mujeeb-Ur-Rahman ${ }^{3}$ and \\ Zahoor Ahmed Bazai ${ }^{1}$ \\ 1. Botany Department, University of Balochistan, Quetta Pakistan. \\ 2. Chemistry Department, University of Balochistan, Queta Pakistan. \\ 3. PCSIR Laboratories, P.O. Box 387, Mastung Road, Quetta, Balochistan, Pakistan. \\ *Corresponding author's email: profakk@yahoo.com
}

Citation

Abdul Kabir Khan Achakzai, Samiullah, Mujeeb-Ur-Rahman and Zahoor Ahmed Bazai. Occurrence and health hazard status of aflatoxin in human food and animal feed of wheat from Pakistan: A review paper. Pure and Applied Biology. Vol. 4, Issue 4, 2015, pp 611-619. http://dx.doi.org/10.19045/bspab.2015.44021

Received: $16 / 08 / 2015 \quad$ Revised: 02/11/2015

Accepted: $11 / 11 / 2015$

\section{Abstract}

Aflatoxins (Afs) are the most important and naturally occurring health hazard mycotoxin which is carcinogenic and mutagenic found mainly in cereal grain food and feeds. Disease caused by ingestion of aflatoxin through food and feed are called aflatoxicosis. They cause hepatocellular carcinoma (HCC), or liver cancer mainly in humans and some animals. Considering its significant impact on human, animals and poultry health, the main aim of the present review is to provide a comprehensive overview on Afs affecting human food and animal feed of wheat from Pakistan. Afs are principal toxic secondary metabolites produced by toxigenic fungal plants (viz., Aspergillus flavus and A. parasiticus) on host crops either before harvest or post-harvest mainly during grain storage period. Research focuses that there are two main external factors e.g. humidity and temperature which affect the incidence of Afs producing Apergillus species. Warm and humid climatic condition prevails in most of the agricultural land of Pakistan. Humidity encourages Aspergillus to attack the wheat grains. Favorable condition for its growth is high temperature and high moisture content $(>7 \%)$. The optimum temperature for Afs production is recorded as $30^{\circ} \mathrm{C}$. In Pakistan very little information regarding Afs status of cereal grains is available on toxicological data in general and wheat grains in particular. But few researchers highlighted the presence of Afs in wheat food and feeds. Based on their limited published work I found a mixed trend regarding the status of Afs in wheat food and feeds. Some analyzed samples were found above, and some were below the health hazard limit or permissible limit as proposed by European Union (EU) and FDA (US Food Drug Administration). Therefore, more research is needed to be carried out on the potential threats to human beings, animals and poultry after consumption of Afs contaminated wheat food and feeds.

Key words: Aflatoxin (Af); wheat; food; feed; mycotoxin; aflatoxicosis

Introduction

Wheat (Triticum aestivum L.) is an important food crop grown throughout the globe. It is the third most produced cereal grain after maize and rice crops. It is a staple food of billions of people. China, India, 
USA, France, Russia, Australia, Canada, Pakistan, Germany and Turkey are the top ten leading countries producing about 125.6; $94.9 ; 61.8 ; 40.3 ; 37.7 ; 29.9 ; 27.0 ; 23.5 ; 22.4$ and 20.1 million metric tones, respectively [1]. In Pakistan, wheat is the topmost cereal crop cultivated on 8649.8 thousand hectares by producing 25979.4 thousand tones during growing year 2013-14 [2].

Many agricultural commodities are vulnerable to attack by a group of fungi that are able to produce toxic secondary metabolites known as mycotoxins. There are more than six common mycotoxins viz. Aflatoxin, Ochratoxin, Fumonisins, Zearalenone, Trichothecenes and Patulin [3]. Aflatoxins (Af) are one of the most important and naturally occurring toxin were first discovered in Europe in animal feed. Af are found as contaminants in various agricultural commodities such as oats [4]; nuts [5]; maize [6]; oil seed crops [7]; chilli [8]; wheat [3]; rice [9]; sorghum [10], and spices [11]. Among various mycotoxins, Af were assumed significant due to their deleterious effects on human beings, poultry and livestock. Approximately, 5-10\% of agricultural commodities world wide are spoiled by fungi, to the extent that crops can not be consumed by human, animal and birds (poultry). This situation is more serious particularly in developing countries like Pakistan, where there are poor agricultural, harvesting, storage, transportation and marketing conditions, which ultimately lead to fungal growth and increase the risk of mycotoxin in general and aflatoxin in particular [12]. According to reliable estimate, mycotoxin affect $1 / 4^{\text {th }}$ of the world's food crop which includes many basic food and feed stuffs of human and animals [13]. Studies also showed that food contamination by Af may develop as a result of respective fungal attack before or during wheat harvest, or during storage [14].

\section{Fungus Producing Aflatoxins (Afs)}

Afs are mostly produced by filamentous fungi known as Aspergillus. This genus is distributed world wide and contains over 180 species. It is one of the most cosmopolitan and abundant of all groups of fungi, and also one of the most studied fungal groups $[15,16,17]$. They can colonize and contaminate grain before harvest or during storage. This is also a type of phytopathogenic organisms that infect crops and fruits [18]. Aspergillus flavus; Aspergillus parasiticus; Aspergillus nomius and Aspergillus niger are the common fungal plants which can contaminate cereals (including wheat); food, vegetable, fruits, and cattle feed [19]. The Af quantity also depends on Aspergillus strain [20, 21].

\section{Types of Aflatoxins}

Aflatoxins (Afs) are the most potent carcinogens both in human and animal populations. In fact, the toxin-producing fungus was identified as Aspergillus flavus (1961) and the toxin was given the name Aflatoxin by virtue of its origin $(A$. flavis ------> Afla). There are more than 20 different types of aflatoxins (Af), but the most important and naturally occurring major members of Af in food and food stuffs are $\mathrm{AfB}_{1}, \mathrm{AfB}_{2}, \mathrm{AfG}_{1}, \mathrm{AfG}_{2}, \mathrm{AfM}_{1}, \mathrm{AfM}_{2}$. The last two are produced in milk and milk products. While among all these, $\mathrm{AfB}_{1}$ is the most toxic, abundantly occurring and well studied one is produced by both Aspergillus flavus and Aspergillus parasiticus [22, 23]. Letters ' $B$ ' and ' $G$ ' refer to its blue and green fluorescence colors produced by these compounds when exposed under UV light.

\section{History of Aflatoxins (Afs)}

The Afs represent a group of secondary fungal metabolites which were first discovered in Europe as contaminants of certain lots of animal feeds in year 1960. These toxic contaminants have a high order of acute toxicity both to human and many other animal species viz., chickens, swine, 
cattles, horses etc and also have shown to possess potent carcinogenic properties in several animals (including human). Their discovery in agriculture based animal feed and the subsequent demonstrations of various biological effects resulting from ingestion of contaminated diets by domesticated animals and birds have emphasized the potential public hazard which might arise from contamination of the food supply by mycotoxin in general and Af in particular [24]. The first report of the toxicity syndrome in term of mortality of domestic animals were recorded in young turkeys [25], followed by the same sort of incidents in ducklings, and chickens [26], as well as in swines and calves $[27,28]$.

\section{Chemistry of Aflatoxins (Afs)}

They are secondary metabolites produced by the moulds on food and feed stuffs. Though there are more than 20 naturally occurring Afs, but the most important one are $\mathrm{AfB}_{1}$, $\mathrm{AfB}_{2}, \mathrm{AfG}_{1}$ and $\mathrm{AfG}_{2}$. Af $\mathrm{B}_{2}$ and $\mathrm{AfG}_{2}$ are the dihydro derivatives of the parent
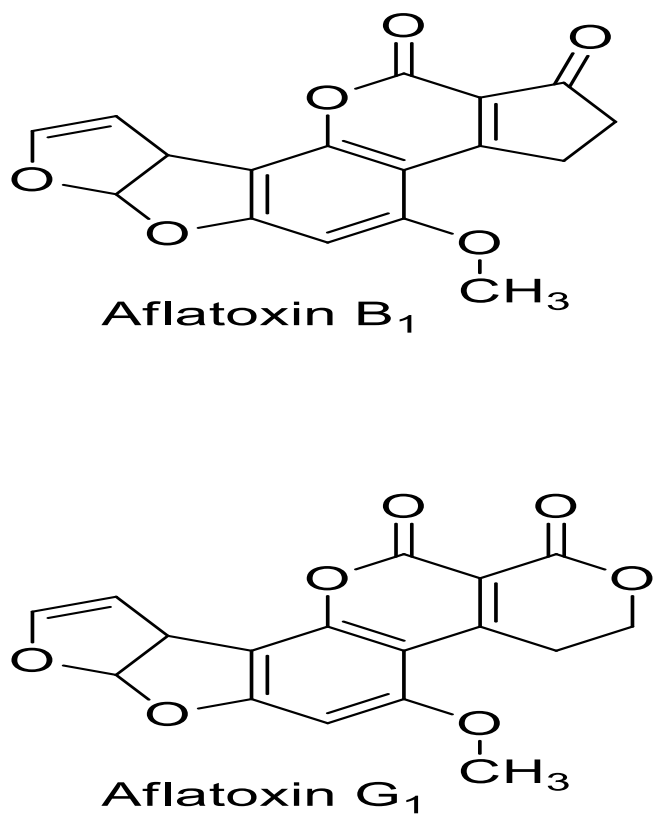

compounds (Fig. 1). They all exist as colorless to pale-yellow crystals at room temperature [29]. They are oxygenated hydrocarbons and are slightly soluble in water, soluble in organic solvents like methanol, acetone, and chloroform, and insoluble in non-polar solvents. Dichloromethane has good solubility for aflatoxins and has been used in analytical procedures to extract and purify aflatoxin for their assay. Aflatoxins are relatively unstable in light and air, particularly in polar solvents or when exposed to oxidizing agents, ultraviolet light, or solutions with a $\mathrm{pH}$ below 3 or above 10. There are various isoforms of Af viz. $\mathrm{B}_{1}, \mathrm{~B}_{2}, \mathrm{G}_{1}, \mathrm{G}_{1}$. Afs decompose at their melting points, which are between $268-289^{\circ} \mathrm{C}\left(\mathrm{B}_{1} \& \mathrm{~B}_{2}\right)$ and 237 $246^{\circ} \mathrm{C}\left(\mathrm{G}_{1} \& \mathrm{G}_{2}\right)$, but are not destroyed under normal cooking conditions (Table 1). They can be completely destroyed by autoclaving in the presence of ammonia or by treatment with bleach [30].
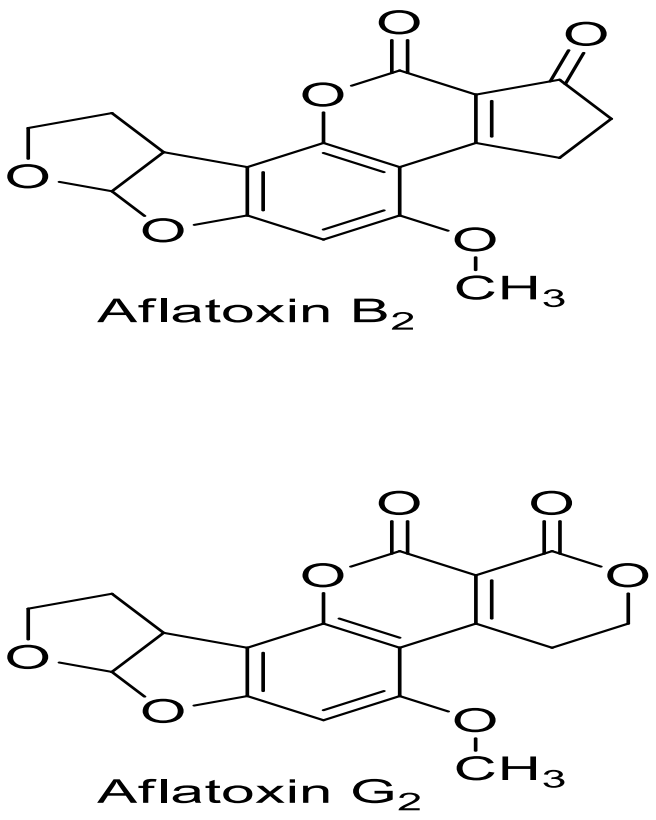

Fig 1. Common aflatoxins (Afs) found in wheat food and feeds. 
Table 1. Physiocochemical characteristics of aflatoxins (Afs) found in wheat food and feeds.

\begin{tabular}{|c|c|c|c|c|c|c|c|c|}
\hline \multirow[t]{2}{*}{$\begin{array}{c}\text { Aflato } \\
\text { xins } \\
\text { (Afs) }\end{array}$} & \multirow[t]{2}{*}{$\begin{array}{l}\text { Molecular } \\
\text { weight }\end{array}$} & \multirow[t]{2}{*}{$\begin{array}{l}\text { Molecular } \\
\text { Formula }\end{array}$} & \multirow[t]{2}{*}{$\begin{array}{c}\text { Melting } \\
\text { Point } \\
\left({ }^{0} \mathrm{C}\right)\end{array}$} & \multirow[t]{2}{*}{$\begin{array}{c}\text { Storage } \\
\text { Temperature } \\
\left({ }^{0} \mathrm{C}\right)\end{array}$} & \multirow[t]{2}{*}{$\begin{array}{c}\text { Optical } \\
\text { rotation } \\
{[\alpha] D * *}\end{array}$} & \multirow{2}{*}{$\begin{array}{c}\text { Fluores } \\
\text { cence/ } \\
\text { UV } \\
\text { absorba } \\
\text { nce }\end{array}$} & \multicolumn{2}{|c|}{$\begin{array}{c}\text { UV absorption } \\
\text { max }(e), n m, \\
\text { methanol }\end{array}$} \\
\hline & & & & & & & 265 & $\begin{array}{l}360- \\
362\end{array}$ \\
\hline $\mathrm{B}_{1}$ & 312.27 & $\mathrm{C}_{17} \mathrm{H}_{12} \mathrm{O}_{6}$ & $\begin{array}{l}268- \\
269 *\end{array}$ & -20 & -559 & $\begin{array}{l}\text { Bright } \\
\text { blue UV } \\
360 \mathrm{~nm}\end{array}$ & 12,400 & 21,800 \\
\hline $\mathrm{B}_{2}$ & 314.29 & $\mathrm{C}_{17} \mathrm{H}_{14} \mathrm{O}_{6}$ & $\begin{array}{l}286- \\
289^{*}\end{array}$ & -20 & -492 & $\begin{array}{l}\text { Bright } \\
\text { blue UV } \\
360 \mathrm{~nm} \\
\end{array}$ & 12,100 & 24,000 \\
\hline $\mathrm{G}_{1}$ & 328.27 & $\mathrm{C}_{17} \mathrm{H}_{12} \mathrm{O} 7$ & $\begin{array}{l}\text { 244- } \\
246^{*}\end{array}$ & -20 & -533 & $\begin{array}{c}\text { Blue- } \\
\text { green } \\
\text { UV } 360 \\
\text { nm }\end{array}$ & 9,600 & 17,700 \\
\hline $\mathrm{G}_{2}$ & 330.29 & $\mathrm{C}_{17} \mathrm{H}_{14} \mathrm{O} 7$ & $\begin{array}{l}237- \\
240 *\end{array}$ & -20 & -473 & $\begin{array}{c}\text { Blue- } \\
\text { green } \\
\text { UV } 360 \\
\text { nm }\end{array}$ & 8,200 & 17,100 \\
\hline
\end{tabular}

*Decomposes and **Chang et al. (1963) [55]

Determination of Aflatoxins (Afs)

Many methods have been used for the determination of aflatoxins in cereal grains (including wheat) and other food materials in the past $[31,32]$. There are so many latest established methods for the determination of Af, but the most common and accurate methods for the determination of Af in food and feed science are: (1) Chromatography e.g., Thin layer chromatography (TLC) [33], Highperformance Liquid Cromatography (HPLC) [34], and Gas Chromatography [35]. (2) Spectroscopy e.g., Fluorescence Spectroscopy (FS) [36] and Frontier Infrared Spectroscopy [37], and (3) Immunochemical methods e.g., Radioimmunoassay (RIA) [38], Enzyme Linked Immunosorbent Assay (ELISA) [39], Lateral Flow Devices (Immunodipsticks) [40] and Immunosensors [41].
Each of the above mentioned analytical procedure for the determination of Af having both merits and demerits. However, chromatographic methods such as TLC and HPLC are considered the gold standard, and are thus the most widely used techniques both in food crops and feeds for aflatoxins analysis.

Diseases Caused by Aflatoxins (Afs) Illness caused by injestion of aflatoxin through food and feed are called aflatoxicosis. Considering the pathogenic effects and aflatoxins of Aspergillus, recorded at different post harvest stages which could be either carcinogenic, cytotoxic, immunosuppressant or estrogenic causing severe disorders both in human and animals. The adverse effects of Afs both in human and animals have been categorized into two main categories: 
a) Acute aflatoxicosis: It is produced when there is moderate to high levels of Afs are injected through contaminated food and feed. Acute aflatoxicosis is characterized by symptoms of hemorrhage, acute liver damage which manifests as severe hepatoxicity as a result of which approximately $25 \%$ fatality rate occurred, edema, issues with digestion and absorption and nutrients metabolism problem also occurred $[42,43]$. Other symptoms of acute aflatoxicosis include hemorrhage (bleeding), edema (swelling of somatic tissue), and changes in metabolism and nutrient absorption, which can ultimately lead to malnutrition. The published out breaks of acute toxicosis in India (1974), Malaysia (1988), and Kenya (1982 \& 2004-05) reflects a mortality rate as high as $60 \%$. While it was recorded as $40 \%$ in Kenya (2004-05) through consumption of contaminated maize. But no any proper published record in Pakistan is available regarding mortality through aflatoxicosi.

b) Chronic aflatoxicosis: It is produced when there is a low to moderate level of Afs are ingested through contaminated food and feed. The effects are usually subclinical and difficult to recognize. Few of the common symptoms are impaired food conversion and slow rates of growth with or without having an overt Af syndrome [44]. In addition to carcinogenic effects, it also causes an immune system problem both in human and animals.

\section{Status of Aflatoxin in Food and Feed of Wheat}

There are about five billion peoples in developing countries of world which are at the risk of chronic exposure to aflatoxins through contaminated food. As compare to develop nations, there have been very few scientific enquiries for Af in wheat food and feed in Pakistan though wheat is being consumed as the topmost staple food by the general public of the country $[45,46]$. A very little attention has been paid to study the mycotoxin in general and Af in particular in wheat food and feed of Pakistan. However, based on limited published literature, the quantity of Af in 56 analyzed wheat samples from Sindh province were not detected within the detectable limits [3]. The studies of [47] indicated an average mean value of $1.42 \mu \mathrm{g}$ $\mathrm{kg}^{-1}$ (Table 2). In another study about $20 \%$ of wheat samples were contaminated by total Afs and the highest level was found in one sample. Among all the contaminated samples, two wheat samples were above the suggested limit $\left(4 \mu \mathrm{g} \mathrm{kg}^{-1}\right)$, and their average mean value of $6.6 \mu \mathrm{g} \mathrm{kg}^{-1}$ was also above the safe limit set by EU regulations (Lutfullah \& Hussain, 2012) [21]. Similarly wheat bran and wheat bread were found to be higher than safe limit recommended by FDA [48]. [49] also stated that out of 19 wheat bran samples, 6 samples were found positive by producing average mean values of $\mathrm{AfB}_{1}$ i.e. $19.0 \mu \mathrm{g} \mathrm{kg}$. However, a maximum level of $39 \mu \mathrm{g} \mathrm{kg}^{-1}$ was also recorded by them. More than eight species of Aspergillus is recorded from stored wheat grains of Pakistan. None of the stored wheat grain samples of three provinces (viz. Punjab, Sindh \& KPK) was found contaminated by Af when analyzed by ELIZA technique [50]. Same results were also obtained by [51] when they analyzed rice for Af concentration.

\section{Factors Affecting Concentration of Aflatosins (Afs)}

There are so many internal and external factors which can affect the rate Afs produced by fungus, particularly by Aspergillus. Generally Afs are affected by pre-harvest and post-harvest conditions, non-scientific methods of grain storage, storage duration, storage season and transportation means. But research studies revealed that there are two main external factors e.g. humidity and temperature [52]. 
Warm and humid climatic condition prevails in most of the agricultural land of Pakistan. Humidity encourages Aspergillus to attack the wheat grains or crop. Favorable condition for its growth is high temperature and high moisture content $(>7 \%)$. The optimum temperature for Afs production is recorded as $30^{\circ} \mathrm{C}$, while no toxin is produced at $10^{\circ} \mathrm{C}$ [53]. The positive control in all the batches of Aspertgillus flavus and Aspergillus parasiticus isolates produced maximum Afs in grains at $16 \%$ moisture, and $25^{\circ} \mathrm{C}$ temperature in a laboratory experiment [54].

Table 2. Average mean values of aflatoxins (Afs) in wheat food and feed samples reported from Pakistan.

\begin{tabular}{|c|c|c|c|}
\hline Wheat Samples & $\begin{array}{c}\text { Aflatoxin mean } \\
\text { values }(\mu \mathrm{g} \text { kg or } \\
\text { ppb) }\end{array}$ & $\begin{array}{c}\text { References and Citation } \\
\text { Number }\end{array}$ & $\begin{array}{l}\text { Safe limits of aflatoxins } \\
\text { (Afs) by EU \& FDA }\end{array}$ \\
\hline Wheat & $5.2 \mu \mathrm{g} \mathrm{kg}$ & Shah (1985) [56] & $\mathrm{EU}(4 \mu \mathrm{g} \mathrm{kg})$ \\
\hline Wheat & $18.88 \mathrm{ppb}$ & Bhatti et al., (2001) [48] & FDA (20 ppb) \\
\hline Wheat & $1.42 \mu \mathrm{g} \mathrm{kg}$ & Qamar et al., (2008) [47] & $\begin{array}{c}\text { EU }(4 \mu \mathrm{g} \mathrm{kg}) \text { and } \\
\text { FDA, USA }(20 \mu \mathrm{g} \mathrm{kg})\end{array}$ \\
\hline Wheat & $6.6 \mu \mathrm{g} \mathrm{kg}$ & $\begin{array}{l}\text { Lutfullah and Hussain (2012) } \\
\text { [21] }\end{array}$ & $\mathrm{EU}(4 \mu \mathrm{g} \mathrm{kg})$ \\
\hline Wheat bran & $24.00 \mu \mathrm{g} \mathrm{kg}$ & Khan et al., (2011) [49] & FDA (20 ppb) \\
\hline Wheat bran & $20.29 \mathrm{ppb}$ & Bhatti et al., (2001) [48] & FDA (20 ppb) \\
\hline Wheat bread & $18.88 \mathrm{ppb}$ & Bhatti et al., (2001) [48] & FDA (20 ppb) \\
\hline
\end{tabular}

EU = European Union; FDA = US Food Drug Administration

\section{Conclusions}

Keeping in view the above mentioned pivotal role of fungi in Afs production in wheat food and feed, it is strongly recommended that seed lots before and after harvest should regularly be monitored through certain modern technologies in order to determine the health hazard status of seeds prior to be locally consumed or exported. The wheat crop seeds contaminated by Apergillus spores should be treated at pre harvest level as a control measure of spread of disease caused by Aspergillus. Present review also suggests that Aspergillus growth needs to be controlled both in fields prior to harvest and post harvest at storage stage before to be consumed by human and animals. The chances of Afs contamination in wheat grains increase on account of high moisture content, and inadequate storage temperature. Therefore, wheat grains must be maintained at proper storage conditions to stop the
Aspergillus proliferation. Post-harvest agricultural practices also need to be properly improved by using the modern technologies in threshing, drying, storage, and transportation of wheat grains. Detoxification and decontamination and cleaning are few other remedies which could be adopted in order to minimize or reduce the rate of Afs contamination. To ensure the health safety of national and international consumers, the concerned regulatory authorities of Pakistan are suggested to take into consideration this serious issue of wheat food and feed contamination caused by fungal growth, and controlling strategies should be practiced and quality control system of food should also be adopted and needs to be improved.

Authors' contributions

Review paper designed: AKK Achakzai \& Samiullah. Literature surveyed: M Rahman. Overviewed: ZA Bazai. Wrote the paper: AKK Achakzai 


\section{References}

1. Anonymous (2012). World Map with Top Ten Countries by Wheat Production. Food and Agriculture Organization (FAO), From FAO State Database.

2. Anonymous, 2015. Pakistan Bureau of Statistics, Statistics House, 21-Mauve Area G-9/1, Islamabad, Pakistan.

3. Sahar N, Ahmed M, Parveen Z, Ilyas A $\&$ Bhutto A (2009). Screening of mycotoxins in wheat, fruits and vegetables grown in Sindh, Pakistan. Pakistan J Biol Science 41(1): 337-41.

4. Stubblefield RD, Shotwell OL, Hesseltine CW, Smith ML \& Hall HH (1967). Production of aflatoxin on wheat and oats: Measurement with a recording Densitometer. Appl Microbiol 15(1): 186190.

5. Boutrif E (1998). Prevention of aflatoxin in pistachios. Food Nutr \& Agric 21: 32-38.

6. Abbas HK, Cartwright RD, Xie W \& Shier WT (2006). Aflatoxin and fumonisin contamination of corn (maize, Zea mays) hybrids in Arkansas. Crop Protect 25: 1-9.

7. Klich MA (2007). Aspergillus flavus: the major producer of aflatoxin. Mol Plant Pathol 8(6): 713-22.

8. Abrar M, Anjum FM, Zahoor T \& Nawaz H (2009). Effect of storage period and irradiation doses on red chillies. Pakistan $J$ Nutr 8(8): 1287-1291.

9. Mohammadi M, Mohebbi GH, Hajeb P, Akbarzadeh S \& Shojaee I (2012). Aflatoxins in Rice Imported to Bushehr, A Southern Port of Iran. American-Eurasian J Toxicol Science 4(1): 31-35.

10. Ratnavathi, CV, Komala VV, Kumar BS, Das IK \& Patil JV (2012). Natural occurrence of aflatoxin B1 in sorghum grown in different geographical regions of India. J Sci Food Agric 92(12): 2416-20.

11. Hammami W, Fiori S, Roda Al Thani, Kali NA, Balmas V, Migheli Q \& Jaoua S (2014). Fungal and aflatoxin contamination of marketed spices. Food Control 37: 177181.
12. Topal S (1993). Gidalarda Küf Kontaminasyon Riskleri Ve Önlemleri (124), pp: 174-187. Kocaeli: TübitakMam, Press.

13. Anonymous (2003). Mycotoxins: Risks in Plant, Animal and Human Systems. Council for Agricultural Science and Technology, Ames, Lowa.

14. Qazi JI \& Fayyaz Z (2006). Aflatoxin contaminated foods and health risk perspective for Pakistani population. Mycopathol 4(2): 27-34.

15. Kurtzman CP, Horn BW and Hesseltine CW (1987). Aspergillus nomius, a new aflatoxin-producing species related to Aspergillus flavus and Aspergillus tamarii. Antonie van Leeuwenhoek 53: 147-158.

16. Dyer PS, (2007). Sexual reproduction and significance of MAT in the Aspergilli. In: Sex in Fungi: Molecular Determination and Evolutionary Implications, Eds., G. Heitman, J.W. Kronstad, J.W. Taylor and L.A. Casselton ASM Press, Washington, DC, pp: 123-124.

17. Speijers GJA \& Speijers MHM (2004). Combined toxic effects of mycotoxins. Toxicol Lett 153: 91-98.

18. Bhat R, Rai RV and Karim AA. (2010). Mycotoxins in food and feed; present status and future concerns. Com. Rev. Food Sci Food Saf 9: 57-81.

19. Asi MR, Iqbal SZ, Arino A \& Hussain A (2012). Effect of seasonal variations and lactation times on aflatoxin M1 contamination in milk of different species from Punjab, Pakistan. Food Control 25: 34-38.

20. Kumar V, Basu MS \& Rajendran TP (2008). Mycotoxin research and mycoflora in some commercially important agricultural commodities. Crop Protec 27(6): 891-905.

21. Lutfullah G \& Hussain A (2012). Studies on contamination level of aflatoxins in some cereals and beans of Pakistan. Food Control 23: 32-36.

22. Payne GA (1998). Process of contamination by aflatoxin-producing fungi 
and their impact on crops. In: Sinha, K.K.S., Bhatnagar, D. (Eds.), Mycotoxins in Agriculture and Food Safety. Marcel Dekker, Inc., New York, pp: 279-306.

23. Ito Y, Peterson SW, Wicklow DT \& Goto T (2001). Aspergillus pseudotamarii, a new aflatoxin producing species in Aspergillus section flavi. Mycol Res. 105: 233-239.

24. Lancaster MC, Jenkins FP \& McL. Philip J (1961). Toxicity associated with certain samples of groundnuts. Nuture 192: 1095 1096.

25. Blount WP (1961). Turkey " $X$ " disease. Turkeys. J Brit Turkey Fed 9: 52, 55-58, 61, 77.

26. Asplin FD \& Carnaghan RBA (1961). The toxicity of certain groundnut meals for poultry with special references to their effect on ducklins and chickens. Vert Rec 73: $1215-1219$.

27. Loosmore RM. \& Harding JDJ (1961). A toxic factor in Brazilian groundnut causing liver damage in pigs. Vet Rec 73: 13621364.

28. Harding JJ, Dones JT, Lewis G \& Allcroft R (1963). Experimental groundnut poisoning in pigs. Res Vet Sci 4: 217-229.

29. Anonymous (1993). Aflatoxins. In Some Naturally Occurring Substances: Food Items and Constituents, Heterocyclic Aromatic Amines, and Mycotoxins. IARC Monographs on the Evaluation of Carcinogenic Risk of Chemicals to Humans, Vol. 56. Lyon, France: International Agency for Research on Cancer. pp. 245-395.

30. Wogan GN (1966). Chemical Nature and Biological Effects of the Aflatoxins. Bacteriol Rev 30(2): 460-470.

31. Garner RC (1975). Aflatoxin separation by high pressure liquid chromatography. $J$ Chromatog 103: 186-188.

32. Anonymous (1984). Official Methods of Analysis of the Association of Official Analytical Chemists (AOAC), 14th edition. Arlington, VA 22209, USA.

33. Betina V (1985). Thin-layer chromatography of mycotoxins. $J$ Chromatog 334(3): 211-276.
34. Kok WT, Van Neer TCH, Traag WA \& Tuinstra LGT (1986). Determination of aflatoxins in cattle feed by liquid chromatography and post-column derivatization with electrochemically generated bromine. J Chromatog A 367: 231-236.

35. Liang Y, Zhang C \& Liu L (2005). Chromatographic analysis of mycotoxins. Zhongguo Weisheng Jianyan Zazhi, vol. 15 , p. 1273.

36. Babu D (2010). Rapid and Sensitive Detection of Aflatoxin in Animal Feeds and Food Grains Using Immunomagnetic Bead Based Recovery and Real-Time Immuno Quantitative PCR (RT-iqPCR) Assay, Oklahoma State University.

37. Mirghani MES., Man YBC, Jinap S, Baharin BS \& Bakar J (2001). "A new method for determining aflatoxins in groundnut and groundnut cake using Fourier transform infrared spectroscopy with attenuated total reflectance". J Amer Oil Chem Soc 78(10): 985-992.

38. Rauch P, Fukal L, Prošek J, Březina P \& Káš J (1987). Radioimmunoassay of aflatoxin $\mathrm{M}_{1}$. J Radioanal. \& Nuclear Chem 117(3): 163-169.

39. Ondieki D, Lutta ST, Okoth MO \& Kering P (2014). Rapid assessment of aflatoxin contamination of groundnuts by thin layer chromatography and competitive enzyme linked immunosorbent assay from selected divisions of Busia County in Kenya. Afr J Dood Sci \& Technol 5(1): 1220.

40. Ho JA \& Wauchope R (2002). A strip liposome immunoassay for aflatoxin $\mathrm{B}_{1}$. Anal Chem 74(7): 1493-1496.

41. Linting Z, Ruiyi L, Zaijun L, Qianfang X, Yinjun F \& Junkang L (2012). An immunosensor for ultrasensitive detection of aflatoxin $B_{1}$ with an enhanced electrochemical performance based on graphene/conducting polymer/gold nanoparticles/the ionic liquid composite film on modified gold electrode with electrodeposition. Sensors and Actuators B: Chemical 174: 359-365. 
42. Strosnider $H$, Azziz-Baumgartner $E$, Banziger M, Bhat RV, Breiman R, Brune MN, DeCock K, Dilley A, Groopman J, Hell K, Henry SH, Jeffers D, Jolly C, Jolly P, Kibata GN, Lewis L, Liu X, Luber G, McCoy L, Mensah P, Miraglia M, Misore A, Njapau H, Ong CN, Onsongo MT, Page SW, Park D, Patel M, Phillips T, Pineiro M, Pronczuk J, Rogers HS, Rubin C, Sabino M, Schaafsma A, Shephard G, Stroka J, Wild C, Williams JT and Wilson D. 2006. Environ Health Perspect 114(12): 1898-1903.

43. Kumar CB, Reddy BSV, Gloridoss RG, Prabhu TM, Suresh BN \& Kumar SN (2015). Amelioration of aflatoxicosis through a bio-technologically derived aflatoxin degrading commercial product in broilers. Pak Vet J 35(2): 217-221.

44. Walderhaug M (1992). Ciguatera. Foodborn Pathogenic Microorganusms and Natural Toxins Handbook. Food and Drug Administation, USA.

45. Shepherd GS (2003). Aflatoxin and Food Safety: Recent African Perspective. $J$ Toxicol 22(2\&3): 267-286.

46. Phillips TD (2004). Human aflatoxicosis in developing countries: a review of toxicology, exposure. Potential health consequences and interventions. Amr. J Clin Nutr 80(5): 1106-22.

47. Qamar MA, Rakhshanda N, Muhammad RA, Khalil R, Haq NB \& Kauser P (2008). Analysis of aflatoxins in the cereals from hepatic affected areas in Faisalabad, Pakistan. Int J Agri Biol 10: 140-44.

48. Bhatti BM, Talat T \& Sardar R (2001). Estimation of aflatoxin $\mathrm{B} 1$ in feed ingredients and compound poultry feeds. Pak Vet J 21(2): 57-60.

49. Khan SH, Hasan S, Sardar R and Anjum MA (2011). Occurrence of Aflatoxin B1 in Poultry Feed and Feed Ingredients in Pakistan. Intern. J for Agro Vetern \& Med Sci (IJAVMS) 5(1): 30-42.

50. Maliha R, Samina K \& Najma A (2010). Assessment of mycoflora and aflatoxin contamination of stored wheat grains. Intern Food Res J 17: 71-81.

51. Carlos L, Orsi RB, Dilkin P \& Correa B (2000). Mycoflora and aflatoxigenic species in derivatives of milled rice. Ciencia e Tecnologia de Alimentors 20: 3739.

52. Sabahat S (2010). Determination and Reduction of Aflatoxin by Gamma Irradiation in Wheat Maize and Rice. $\mathrm{PhD}$ Thesis, University of Agriculture, Pakistan.

53. Ogundero VW (1987). Temperature and aflatoxin production by Aspergillus flavus and A. parasiticus strains from Nigerian groundnuts. J Basic Microbiol 27(9): 511514.

54. Rashid M, Khalil S, Ayub N, Ahmed W \& Khan AG (2008). Categorization of Aspergillus flavus and Aspergillus parasiticus isolates of stored wheat grains into Aflatoxinogenics and nonaflatoxinogenics. Pak J Bot 40(5): 21772192.

55. Chang SB, Abdel Kader MM, Wick EL \& Wogan GN (1963). Aflatoxin B2: chemical identity and biological activity. Science 142: 1191-1192.

56. Shah FH (1985). Aflatoxins in Agricultural Commodities. Pakistan $J$ Med Res 24, (3): 133-136. 